Joksić Ivan*

Rajaković Vesna**
UDK: 159.922.8

Review article

DOI 10.5937/ptp2004042J

Received: 24.08.2020.

Approved on: 14.10.2020.

Pages: 42-54

\title{
FAMILY AS A FACTOR OF SOCIALIZATION AND RESOCIALIZATION
}

\begin{abstract}
A family represents the basic unit of the society. It has a crucial influence on developing both positive and negative tendencies in the young population. A social role of a family comprises the active relationship of its senior members, especially the parents, in the process of socialization of the youngs - children and minors. In a process of resocialization, a proper positioning of family members represents the highest achievement in the realization of its social role. In such a way, a family gives an active contribution to affirming the positive social values. However, the expected social role of the family is often being corrupted by the deviant and criminal behavior of its junior members. Thus, this is a clear signal that the socialization was unsuccessful. The reasons may be found in its partial or complete deficiency.

When a family fails to complete its role, then we have on the scene the members of the young population who do not comply with moral and legal norms. Consequently, they must be subjected to a process of resocialization. This process includes various subjects: the court, social welfare center, local community, school, family and the offender him/herself. They jointly participate in a resocialization process as a form of rehabilitation. Although in this process the family role is being realized within the legal frames (issued sentences or decisions), it is undisputable that it plays the important role. Hence, we find necessary to point out the specific role of the family as a factor in the socialization and resocialization process.
\end{abstract}

Key words: family, socialization, resocialization, the Social Welfare Center.

\footnotetext{
* Associate professor at the Faculty of Law for Commerce and Judiciary in Novi Sad, Serbia, e-mail: ijoksic@hotmail.rs

** Assistant professor at the Faculty of Law for Commerce and Judiciary in Novi Sad, Serbia, e-mail: vesnarajakovic@yahoo.com
} 


\section{Introductory notes}

Family has always been a haven for its members. In the family environment, they have formed their characters and stands to the society. A historical survey of family relationships' evolution comprises different phases in its development. At first, the collective consciousness dominated in people whose basic part had originated from the family. The individual was a part of a collectivity in which he inevitably belonged and was implicitly submissive to. Family authorities were its senior members. Their role was to provide economical functioning of other family members.

The traditional family relationships were based on shifting between the patriarchy and matriarchy. Practically, it reflected in gender dominance of the senior family members. However, in each phase of a family development, the issue of mandatory submission of the juniors to seniors has never been questioned. Moreover, the generation resistance of family members has gained its latent forms, but was never able to question the survival of the seniors' authority. The submission consciousness of the juniors in relation to the decisions of the seniors was deeply rooted and indisputable all way to the second half of the last century. The individual cases of rebellious relationship of the children towards their parents and senior family members were considered to be a sort of a family heresy which had to be nipped at the bud.

Various methods of family classification can be found in the literature, with full recognition of both historical and geographical specificities. Authors tend to approach this issue, with consideration to present features that influenced the family reform. Hence, we may find different family types. Their number varies depending on the character study of relationships between family members. We can be satisfied with a dichotomous classification of all family types by diving it into: the traditional (authoritative) and the modern (democratic) family. This distinctive polarization of the family is of a general character. That is why we may separate more subtypes of the family.

The traditional or authoritative family rests on rooted positions of its members. Focal point in a family relationship is the supreme authority of the eldest male family members. They are considered to be "the head of the family" and have to be humbly obeyed by the other parts of the family structure. The socialization in such families was deeply rooted in the moral and common rules. Forming of consciousness of the youngest members was based on the adoption of the stands and opinions of its senior members, without the possibility to doubt the justification of certain actions and behaviors. The explicit imbalance of power within the family had enabled the socialization 
in the sense of transferring the experience of the seniors to juniors. The important part in building the family relationships in the traditional family implies the absence of free consent in the process of resocialization. This lead to the obedient acceptance of already rooted behavioral patterns, without the possibility for its modification. Female family members and children were restrained which reflected in killing any initiative or possibility of creating a life of their own. Subsequently, the use of force for breaking any active or expected resistance towards family authorities was considered to be fully legitimate and eligible way of re/socialization.

The modern or democratic family represents an antipode to everything represented by the traditional family. It rests on the modern approach in establishing and nurturing family relationships. Its focal point is the desire for adoption new values based on human approach. Inter-family relationships implied the presence of family authorities, but in different sense than the traditional patterns of socialization. Family authority was not based on a submissive character, but on adopting positive social values. This family type was characterized by the mutual honor and respect of all family members without the possibility of compulsorily imposing the stands and opinions to junior family members. The social community has been actively involved in building the socially acceptable behavioral patterns and adopting the system of modern society values. Parenting and achieving professional goals of the parents, stood as a model to their children.

But, besides positive tendencies, modern family is also characterized by the presence of negative tendencies. They include many problems, such as: poverty, lack of quality time for children, drug addiction, alcoholism, domestic violence, etc. These situations impose a new role to the family as a participant in a resocialization process of the children and minors. Family becomes an active factor of the socialization, acting within legal frames. Simultaneously, it becomes one of the subjects to participate in the resocialization of the junior members.

\section{Family as a factor of socialization}

Family is the basic unit of the social organism that contributes its normal functioning. Designated in this way, family is considered to be the important part of a social structure which produces new members. ${ }^{1}$ Within a family, dif-

\footnotetext{
${ }^{1}$ Vulević, P. (2019). Zaštitna uloga porodičnog zakona u svetlu rehabilitacije osoba sa poremećajem $\mathrm{u}$ ponašanju, [Family law protection in light of rehabilitation of persons with conduct disorder]. Pravo - teorija i praksa 36 (10-12), p. 60.
} 
ferent processes take place and contribute building of positive values among the youngest population. One of these processes is the socialization or parenting education. It includes a manner of passing on the experience from seniors to juniors. As the socialization is being primarily the anthropological and psychological term, it is the sociology that gives it the importance of a factor that enables the individual to be prepared for social life. ${ }^{2}$

On discussing the family as a factor of socialization, it is necessary to designate various significant moments, which interact both positively and negatively within this frame. In a modern society, there is a prevalence of significantly more determining moments acting as the influential factors in the process of socialization. Its number increases daily, but it is important to point out those with the strongest influence in this field.

A) The first moment relates to the altered social, family and personal roles of the individual family members. It is especially the case when it comes to realizing the correlation between the eldest and the youngest family members. Earlier, there had been a long standing practice of caring and upbringing juniors (grandchildren) by the seniors (grandmothers and grandfathers). They had the richest life experience and patience, but also the time to tackle the upbringing of their grandchildren. One of the reasons may be the lack of outdoor activities of the eldest, leaving them to babysitting and tutoring children instead. $^{3}$

Modern society gradually erases generation gaps. It can be seen in a way of behaving, wearing clothes, personal mind-sets, etc. Hence, the traditional forms of socialization are being abandoned and alternated by so called institutionalized education of the children. The pedagogical role of the eldest family members is no longer feasible, as the modern family nowadays consists of two generations (parents and children). Instead, the kindergartens, sport associations or private forms of children's socialization have more dominant social role. They are supposed to fulfill high expectations, standing on a point that experts in their fields have more knowledge to introduce the children into society and contribute to their proper positioning.

b) The other moment considers the altered system of values in the society. The traditional and modern families differ in valuing young people's behavior!

\footnotetext{
${ }^{2}$ Dimitrijević, S. (2014). Porodica kao agens socijalizacije u tranzicionom društvu, [Family as the Agent of Socialization in Transitional Society]. Zbornik radova Filozofskog fakulteta, 45 (1), p. 238.

${ }^{3}$ Ilić, M., Mihajlović, T. (2016). Predinstitucionalno vaspitanje i obrazovanje Srba, [Preinstitutionalized Pedagogy and Education of the Serbs]. Sinteze, 5 (9), p. 17.
} 
In a traditional family, the process of socialization of the youngest members was based on copying the attitudes of the ancestors. Here, the important role rested on the faith and tradition, i.e. customs. In such families and social environment, the children grew up and turned into adults. By coming of an age, they were becoming parents and from today's perspective, prematurely taking over the important social roles. ${ }^{4}$

Modern family stands on diametrically opposite foundations than the traditional family. Different processes take place within these families which together have both positive and negative impacts to the socialization process of its youngest members. It is the young individual who independently chooses the values and the autonomous type of the values. The parents' duty is to introduce their children to the alternative values, pointing out its meaning and consequences. ${ }^{5}$ Here, the parenting is based on directing the children in order to make the right choice and not on imposing the pre-engineered behavioral patterns which must be obeyed without discussion or prior perception of its essence and meaning.

c) The third moment comprises the media influence in the process of children's socialization. Focal point in studying the media influence in socialization may be divided into several sub-units. The reason for the aforementioned rests in the development of media scene and technological progress which allow placement of various "uncensored" contents to the children. The literature recognizes educational function of the media, bringing it to the level of other socialization agents in the socialization of children and young people. Educational goals through mass media are being realized in their ability to convey rich cultural heritage. "Contents emitted through means of mass media communication can contribute to establishing or questioning the traditional values and creating new values accordingly, following the tendencies of the modern society. Mass media have the power to set an agenda for a public debate and action, point out on deviant and dangerous patterns of behavior, be a key factor in preserving status quo or bringing the change, drawing the

\footnotetext{
4 "People strenuously break old habits, prejudices, behaviors and values. The relationship to the tradition is one of the key aspects from which all other relationships related to projecting the society into the European and transatlantic structures derive from. This relationship requires fundamental re-evaluation, as it is linked in the most direct manner with the preservation/loss of national and cultural identity (in Serbia and other countries in the Balkans). Troubles with the tradition come from the misinterpretation of its essence". Božilović, N. (2010). Tradicija i modernizacija (evropske perspektive kulture na Balkanu) [Tradition and Modernization (European Perspectives of the Culture in the Balkans)]. Sociologija, 53 (2), p. 114.

${ }^{5}$ Golubović, Z. (1981). Porodica kao ljudska zajednica [Family as Human Community]. Zagreb, Naprijed, p. 201.
} 
attention to the individuals, events and issues, which is their strongest impact in the sense of public knowledge."

Media influence especially affects modern families. It has an impact on both positive and negative tendencies in upbringing of children as the youngest family members. Unfortunately, we can witness that the modern media scene, consisting of TV, radio and Internet, has huge impact in the socialization role of the family. Media influence is partially indirect. It interacts within already formed structure of social and family relationships and all these elements must be taken into consideration on reaching conclusions of their effects. ${ }^{7}$

d) The fourth moment relates to the role of the school as the important chain in the socialization of children. Nowadays, the school has become secondary factor in socialization, besides the parents as the primary factor. Its role has changed in time and adjusted to new social needs. It was especially noticeable in the era of digitalization and developing learning concept of so called distance learning. Corporation between family and school in the field of socialization includes mutual interaction of both parents and teachers, matching their activities, building positive attitudes in children and distributing impact, in order to let teachers and parents gain full control over the activities undertaken. ${ }^{8}$

e) The fifth moment relates to the increase of uneven economic development leading to imbalance of the social impact between the parents with children of the same age. Uneven economic development among the families represents an important factor in the system of socialization of children in the society. It produces differences in all the segments in a life of an individual which consequently reflects their everyday life. Appreciating all the differences in the economic foundations in the life of children, we cannot accept the pre-engineered pattern in their family socialization. The reasons rest in the uneven economic limitations of the parents who cannot comply with modern society challenges. In practice, we have situations of wealthy families being able to provide more innovative educational content to their children, while the deprived families are unable to do so.

\footnotetext{
${ }^{6}$ Glomazić, H. (2017). Vaspitne mogućnosti masovnih medija [Educational Opportunities of Mass Media] u: Vaspitanje danas - zbornik radova sa savetovanja [Education today - Proceedings from the Conference]. Beograd, Filozofski fakultet Univerziteta u Beogradu i Institut za pedagogiju i andragogiju, p. 191.

${ }^{7}$ Ibid., p. 192.

${ }^{8}$ Milošević, N. (2002). Uticaj saradnje porodice i škole na socijalno ponašanje i školsko postignuće učenika, [Impact of Family and School Collaboration on the Social Behavior and Students' Achievements in School]. Zbornik Instituta za pedagoška istraživanja,, 1 (34), p. 194-195.
} 
The objective scientific approach to the family as a factor of socialization may be recognized through the building of the most acceptable model of parental behavior towards children. It appeared in the U.S.A. in the second half of the past century with the appearance of the Schaefer model. This author separated the dimensions of affection and control in the educational role of the parents.

a) Family's affection dimension was based on the emotional relationship between the parents and children, ranging from warm to cold or refusing and accepting education.

b) Educational control dimension shows the eligible psychological and physical freedom and independence of a child and is being designated as a control dimension located on different poles of permissible and restrictive education.

The Schaefer educational model describes two polarities in which parents and children should build their relationship. In the environment of emotional closeness between parents and children, we can notice their warm relationship. It rests on mutual understanding and corporation between the seniors and the juniors of the family. On the other hand, in the environment of cold relationships between parents and children, the compulsory imposing of one's will is applied. Punishment of the children represents basic form of their socialization and the way of accepting knowledge and experience by the younger members. Parents become more offensive to their children. The relationship of mistrust and mutual intolerance is being instituted. Combining the two control dimensions in the resocialization of the children, one can achieve various parenting styles: warm-permissible, warm-restrictive, coldpermissive and cold-restrictive. Two-dimensional parenting style has been proven unacceptable in the parental practice. Hence, Schaefer introduced the construction of a three dimensional model comprising both positive and negative poles. ${ }^{9}$

In the previous years, our pedagogical practice registers downloading of the international solutions. They involve new forms of children's socialization in which the important role play special programs. They include participation of both parents and children within various programs of international students' exchange. In this way, we get familiar with the educational and pedagogical system instituted in other countries.

\footnotetext{
${ }^{9}$ Acc. to: Vuković, S. (2015). Vaspitni stil roditelja u kontekstu porodične funkcionalnosti i stresa roditeljske uloge, [Parenting Style in the Context of the Family Functionality and the Parental Role Stress]. Niš, Filozofski fakultet, pp. 60-61.
} 


\section{Family as a factor of resocialization}

Resocialization relates to the process of elimination the improper socialization in minors. This mainly concerns to neglected minors who have already entered the incrimination zone of performing one or several criminal offences. Thus, they become a part of the criminal milieu in their environment. The reasons for such deviant and criminal behavior in young population should be sought in the wider social community. This includes mistakes done by multiple separate subjects that mutually participate in the socialization of the children and minors, such as: family, school, Social Welfare Center, police, non-governmental sector, etc. They mutually participate in building the positive attitudes and values in children and minors.

By passing The Law on Juvenile Criminal Offenders and Criminal Protection of Juveniles (The Law on Juveniles), Serbia tackled the complete regulation of juvenile matter. ${ }^{10}$ In this legal act, the system of juveniles' resocialization was amended by introducing new penal measures (sui generis). These measures are not instituted in order to substitute the penal sanctions, but rather used as the alternative in the situations when it is not compulsory to apply the penal repression to juveniles. "The purpose for introducing these measures was mainly practical and it included the option of influencing juvenile offenders by the measures of a diversion character, which do not comprise the elements of repression. By doing so, the criminal procedure diverts and provides the option of juvenile offender's rehabilitation, without the implementation of the measures (sanctions) which comprise the elements of restriction and repression." 11

The application of the diversion orders may include several subjects which execute its role within the legally stipulated frame. Within the application of diversion orders, the important segment in the resocialization of juveniles falls on the family. Its role reflects in active participation, while performing the abovementioned obligations within each of the prescribed diversion orders. It can be said that the family has the status of the most influential subject in the establishment of moral orientation in young population. ${ }^{12}$

\footnotetext{
${ }^{10}$ Zakon o maloletnim učiniocima krivičnih dela i krivičnopravnoj zaštiti maloletnih lica [The Law on Juvenile Criminal Offenders and Criminal Protection of Juveniles], Službeni glasnik RS, no. 85/05. ${ }^{11}$ Joksić, I. (2007). Specifičnosti alternativnih mera (vaspitni nalozi) u krivičnom zakonodavstvu Srbije [Specificities of the Alternative Measures (Diversion Measures) in the Criminal Legislation of Serbia], NBP, 12 (3), p. 135.

${ }^{12}$ Budimir-Ninković, G. (2006). Savremena porodica i škola [Modern Family and School]. Jagodina, Učiteljski fakultet, p. 25.
} 
On choosing the concrete diversion order, one must take into consideration the entire well-being of both parties (the juvenile perpetrator and the injured party). Also, one must take into consideration the need for regular school attendance and juvenile's employment. In that sense, it is crucial to have a good relationship with the parents, guardians or adoptive parents, as well as the Social Welfare Center. ${ }^{13}$

„Juvenile criminal sanctions are specific kind of criminal sanctions designed for certain age group of criminal offenders (juveniles) that, prior to issuing a court decision, are being preceded by the special form of the court procedure (criminal procedure of juveniles), special conditions for its ordering (conditions for diversion orders and juvenile detention), as well as the special and separate institutions for the execution of the ordered sanctions by remanding a juvenile to an institution (correctional/rehabilitation institution and juvenile detention). ${ }^{\text {"14 }}$

Criminal sanctions ordered to juveniles contain the application of the special treatment with the purpose of resocialization of personality of a juvenile offender. The legislator divided them into diversion measures and sentence to juvenile prison. Diversion measures are basic criminal sanctions to the juveniles. Its importance is reflected in the fact that they can be imposed exclusively to this age group of perpetrators. ${ }^{15}$

The application of diversion measures is not unique in practice. Organizing the educational treatment with a juvenile's family as the focal point implies various forms of its involvement. This is especially visible in diversion orders known as the increased supervision. In such cases, family acts as the active participant in the application of the diversion treatment. Hence, its differentiation is based upon the organization of the treatment within the same family, other family, along with active participation and simultaneous supervision by the Social Welfare Center.

Juvenile prison is the only sentence which may be ordered to an elder juvenile. Being an institutionalized penal sanction, it immensely modifies the role of a family in the resocialization of a juvenile, compared to a diversion measure of the increased supervision. Here, the family plays its role in the

\footnotetext{
${ }^{13}$ Nikolić, Z., Joksić, I. (2011). Maloletnička delinkvencija (socijalnopsihološki i krivičnopravni aspekti) [Juvenile Delinquency (Socio-psychological and Criminal Aspects)]. Beograd, Institut za kriminološka i sociološka istraživanja, p. 142.

${ }^{14}$ Ibid., p. 143.

${ }^{15}$ Radovanov, A., Joksić, I. (2018). Položaj maloletnika u porodičnom i krivičnom pravu Republike Srbije [Position of Juveniles in Family and Criminal Law of the Republic of Serbia], Vojno delo, $70(6)$, p. 162.
} 
post-penal period. It starts with ordering the suspended sentence and lasts till its termination and final return of a juvenile offender into the society. The criminologists concur that a successfully institutionalized resocialized juvenile offender returns to criminal activities without exception if the post-penal acceptance is not successfully organized. In this phase, family plays key role. It provides sanctuary and financial support till he finds a job and continues his schooling.

\section{Conclusion}

The historical development of a family and family relationships cannot be followed without the insight into its first forms. This implies the primordial clan tribal organization and the emergence of the first city-states. Here, family has been changing in accordance with its social role in different time periods. Besides, in the same moment of time, family was differently organized in separate countries which additionally speak of its social dependency. This is why the sociologists refer the family to be the basic unit of the society it derives from.

In literature, we find two basic type of families: the traditional and the modern one. The internal relationships in these families are regulated in different ways, which entirely modifies the social role of the senior members to juniors. Summing up the different family statuses within societies, it is possible to detect its double role to the younger members. This is an issue of the family as a factor of socialization and resocialization.

As a factor of socialization, family has its primary social role. It reflects in transferring the family's experience of the senior members to the juniors and help them in adopting the positive social values. Therefore, the family exercises its preventive role as it stops the criminal development of a personality in children and minors. As a resocialization factor, family has a corrective role in the rehabilitation of juveniles who broke social and criminal norms. Here, the family enters into the circle of other subjects (court, Social Welfare Center, school, etc.) which mutually apply various forms of juvenile treatments. 


\section{Joksić Ivan}

Prof. dr, Pravni fakultet za privredu i pravosuđe u Novom Sadu, Univerzitet Privredna akademija u Novom Sadu, Srbija

\section{Rajaković Vesna}

Doc. dr, Pravni fakultet za privredu i pravosuđe u Novom Sadu, Univerzitet Privredna akademija u Novom Sadu, Srbija

\section{PORODICA KAO FAKTOR SOCIJALIZACIJE I RESOCIJALIZACIJE}

REZIME: Porodica predstavlja bazni deo jednog društva. Ona ima presudan uticaj na razvijanje pozitivnih i negativnih tendencija kod mlade populacije. Društvena uloga porodice podrazumeva aktivan odnos njenih starijih članova, naročito roditelja, u socijalizaciji mladih - dece i maloletnika. Pravilno pozicioniranje članova porodice, u procesu resocijalizacije, predstavlja najviši domet u ostvarenju njene društvene uloge. Na taj način porodica aktivno doprinosi u afirmaciji pozitivnih društvenih vrednosti. Međutim, očekivana društvena uloga porodice neretko biva narušena devijantnim i kriminalnim ponašanjem njenih najmlađih članova. Time se šalje jasan signal da je socijalizacija bila neuspešna. Razlozi se mogu ogledati u njenom delimičnom ili potpunom izostanku.

Kada porodica nije ostvarila svoju ulogu onda imamo na društvenoj sceni pripadnike mlade populacije koji ne poštuju moralne i pravne norme. Zato je neophodno pristupiti njihovoj resocijalizaciji. $U$ tome aktivnu ulogu ima više subjekata: sud, centar za socijalni rad, lokalna zajednica, škola, porodica ali i sam prestupnik. Oni skupa učestvuju u procesu resocijalizacije kao obliku vaspitnog popravljanja. Iako se u ovom procesu uloga porodice ostvaruje u pravnim okvirima (presuda, rešenje) nesporno je da ona ima važnu ulogu. Otuda je neophodno ukazati na specifičnu ulogu porodice kao faktora socijalizacije i resocijalizacije.

Ključne reči: porodica, socijalizacija, resocijalizacija, centar za socijalni rad. 


\section{References}

1. Božilović, N. (2010). Tradicija i modernizacija (evropske perspektive kulture na Balkanu), [Tradition and Modernization (European Perspectives of the Culture in the Balkans)]. Sociologija, 53 (2), pp. 113-126

2. Budimir-Ninković, G. (2006). Savremena porodica i škola, [Modern Family and School]. Jagodina, Učiteljski fakultet

3. Dimitrijević, S. (2014). Porodica kao agens socijalizacije u tranzicionom društvu, [Family as the Agent of Socialization in Transitional Society]. Zbornik radova Filozofskog fakulteta, 45 (1), pp. 237-247

4. Golubović, Z. (1981). Porodica kao ljudska zajednica, [Family as Human Community]. Zagreb, Naprijed

5. Glomazić, H. (2017). Vaspitne mogućnosti masovnih medija, [Educational Opportunities of Mass Media] u: Vaspitanje danas zbornik radova sa savetovanja, [Education today - Proceedings from the Conference]. Beograd, Filozofski fakultet Univerziteta u Beogradu i Institut za pedagogiju i andragogiju, pp. 190-194

6. Ilić, M., Mihajlović, T. (2016). Predinstitucionalno vaspitanje i obrazovanje Srba [Pre-institutionalized Pedagogy and Education of the Serbs]. Sinteze, 5 (9), pp. 15-30

7. Joksić, I. (2007). Specifičnosti alternativnih mera (vaspitni nalozi) u krivičnom zakonodavstvu Srbije, [Specificities of the Alternative Measures (Diversion Measures) in the Criminal Legislation of Serbia], NBP, 12 (3), pp. 133-143

8. Milošević, N. (2002). Uticaj saradnje porodice i škole na socijalno ponašanje i školsko postignuće učenika, [Impact of Family and School Collaboration on the Social Behavior and Students' Achievements in School]. Zbornik Instituta za pedagoška istraživanja, 1 (34), pp. 193-213

9. Nikolić, Z., Joksić, I. (2011). Maloletnička delinkvencija (socijalnopsihološki i krivičnopravni aspekti), [Juvenile Delinquency (Sociopsychological and Criminal Aspects)]. Beograd, Institut za kriminološka i sociološka istraživanja

10. Radovanov, A., Joksić, I. (2018). Položaj maloletnika u porodičnom i krivičnom pravu Republike Srbije, [Position of Juveniles in Family and Criminal Law of the Republic of Serbia], Vojno delo, 70 (6), pp. 154-165

11. Vuković, S. (2015). Vaspitni stil roditelja u kontekstu porodične funkcionalnosti i stresa roditeljske uloge, [Parenting Style in the Context of the Family Functionality and the Parental Role Stress]. Niš, Filozofski fakultet 
12. Vulević, P. (2019). Zaštitna uloga porodičnog zakona u svetlu rehabilitacije osoba sa poremećajem u ponašanju, [Family law protection in light of rehabilitation of persons with conduct disorder]. Pravo-teorija $i$ praksa, 36(10-12), pp. 57-71

13. Zakon o maloletnim učiniocima krivičnih dela i krivičnopravnoj zaštiti maloletnih lica, [The Law on Juvenile Criminal Offenders and Criminal Protection of Juveniles]. Službeni glasnik RS, br. 85/05 